\title{
Totalitarianism of Arendt and the Case of Albania
}

\section{$\mathrm{PhD}$ (candidate) Mine Balliu}

\author{
Department of Philosophy, University of Tirana, Tirana, Albania
}

Email address: minef2007@yahoo.com

\section{Doi:10.5901/mjss.2015.v6n4s1p415}

\begin{abstract}
The philosophy of Hannah Arendt in her work "The origins of totalitarianism" (1949), where she analyzes totalitarianism during and after World War II, reveals his three basic characteristics: violence, terror and ideology. All three of these elements were present, even quite evident in Albania during the communist period 1945 - 1990. Listed among the countries of the socialist camp east, under the strong influence of communist ideology, Stalinist dictatorship in Albania has been the most brutal than any other country in the east. With nearly 3 million inhabitants, the statistics show a high percentage of imprisonment, deportation, executions, reprisals against the population, especially against political opponents that did not fit with their ideology. The public and political dimension of the Albanian citizen was shocked too, under the communist. The regime truncated even the private dimension; terror and violence reached out to families. The Albanians were not free, not only within the society, but they were feeling unsure even inside their own families. Albanians were denied physical freedom and are not less but more than 25 thousand prisoners, nearly 80 thousand other political interned in work camps, with some 6 thousands people killed without trial, without mentioning the rest where hundreds of other victims traumatized, maimed or terrorized by psychological violence. Another part of the Albanian society, that was not isolated, was also feeling the same insecure and lonely, despite being formally part of the society, and felt threatened at any moment by possible punishments. Don't all these facts above give us the right to call the 45 - year-old system in Albania a totalitarian system? The paper is an approach and analysis of these three elements in the specific conditions of Albania during the communist regime.
\end{abstract}

Keywords: Violence, Ideology, Communism, Arendt

The twentieth century occupies a very significant weight in the history of Albania not only for the simple fact that Albania gained its independence from the Ottoman Empire (1912), the last of the balkan countries, but because in this century occurred as many events as there never happened before. If the first half of the century, Albania experienced two world wars, survived as a newly established state of the new Balkan reality, in a very difficult road towards recognition, the second half of this century was fatal to the fortunes of the population. After World War II, Albania was aligned in countries with totalitarian system, in orbit of the Soviet Union, a leader and a completely totalitarian country. The inclusion of Albania on the side of totalitarian states was not randomly and immediately, in one day, after World War II. The influence of communist propaganda, since the mid 20's, its intensification in the 30's and the establishment of a communist regime at the end of the War, were the stages when the dictatorship was set in Albania. Some individuals with communist views and ideology exploited ignorance, backwardness of the population, the poor economic and political situation in the country etc., to plant their ideas and laid the foundations of the communist system that would come to power immediately after the War.

The case of Albania is widely analyzed by historians and politicologists of the country and foreigners and all have ranked its regime, 1945-1990, as a country with a left dictatorship. By comparing it with other countries of Europe, Albania is the smallest country in Eastern Europe, but unfortunately it was the poorest and the most isolated country of the so-called socialist camp. Researchers have put forward the idea that to isolation and poverty, we should require the duration of the dictatorial system.

We will discuss and analyze the Albania's case on the light of the work of Hannah Arendt, "The Origins of totalitarianism" (1949). Seeing the similarities, analyzing the facts, evidence and persuasive arguments will show that Albania was a step away from totalitarianism, if not a totalitarian country. Tragic self balance of the victims of the monstrous regime shows that in a population of nearly 3 million people, approximately $1 / 10$ has suffered directly wilderness of that regime.

Not to mention the rest that has been surveyed, psychologically traumatized, especially against political opponents that did not fit with the ideology in power. In comparison with other communist camp, except BS, Albania has a high number of human losses. In 1991 there were, for 45 years, more than 25 thousand prisoners, nearly 80 thousand other 
political interned labor camps, with some 6,000 people killed without trial, without mentioning the rest, hundreds of other victims traumatized, mutilated or terrified because of psychological violence. ${ }^{1}$

Violence and terror, as essential elements of a state dictatorship, according to Arendt, were the basis of the communist regime in Albania. Under the communist government and public policy dimension of Albanian citizens were shocked too. In such a polititcal system the most important institution was Investigating, state security, because this institution produced fear, generated violence, horror. And socialism was administering collective horror. "The emphasis of the police as the only power is a characteristic of all totalitarian regimes."2 The rest of society, which was not isolated feel equally unsafe, because at any moment could become a victim. Arendt points out that totalitarianism is a political system of party regime, where the state seeks the forfeiture of all society activities. People are completely superfluous to totalitarian regimes. In 1945 the government was in the hands of a single party, the Communist Party, later took the name of the Labour Party of Albania. This model was proposed by Stalin, the model to be followed. Since 1945, with the election of December 2, 1945, where even other "entities" were competing, eventually was installed the communist regime, which confirmed as "winning" the Communist Party on 11 January 1946 and certified by the Constitution, as oneparty state, the Communist Party as the only party and leading force in the country, state dictatorship of the proletariat.

The fight against political opponents, who were put on a line with foreign enemies, acknowledged inhuman proportions. Intellectuals, leaders, people who did not agree with Communist regime were killed, and hundred of others were imprisoned and exiled, anywhere in Albania. Police and state security were the terror of the whole society."3 Nobody felt themselves safe. Anyone could be a potential victim. Moreover, as said in a wellknown Albanian intellectual, "the dictatorship began to eat his own children." "Socialism is collective horror administrator. To live in socialism people had to eat dread instead of bread. And Investigation produced horror. " On the other hand only communist ideology was another distinctive feature of the dictatorial regime. Manipulation of the crowds, of the masses was in the highest degree. At first glance all were living "happy" in their poverty and people filled with the image of happiness that did not exist in reality. Arendt states that "... in totalitarian countries propaganda and terror presents two sides of the same coin". ${ }^{4}$

Let us not forget that the new social order that was placed with blood and violence, not against the occupier but against the Albanians, struggle for power, had nothing in common with Western democracy. "Socialism was imaging system. People were happy with nothingness. It was a socialist miracle, "says an architect, painter and publicist, Maks Velo, who suffered communist prisons for over a decade. The fate of the intellectual did not differ with the fate of the citizen. At this point, when he was put in the service of power, ideology, he was treated the same as a simple citizen, trite, if not worse. For them it was not even spared execution. There are not a few but in Albania were killed and imprisoned over 250 artists and writers in 45 years." If in Europe and beyond intellectuals, prominent people were attenders and determinants in many major events, in Albania was not the same thing. Intellectuals were divided into two categories, a part that, willingly or unwillingly, was laid entirely at the service of the local communist, supporters of the communist ideology, and the rest opponents, victims and interned political prisoners.

Arendt is completely right when he says that "totalitarianism is the most abominable theory or political and social practices, because no one feels safe and de facto is not safe and free. The total state is omnipotent state of helpless individuals ".6

Setting the dictatorial regime in Albania, long way of this regime is almost the same as with any other country of the socialist camp. Each state acted on the instructions of Stalin and of the Communist International. As is known, after the First World War, Europe was engulfed in powerful totalitarian movements, but in Albania this regime was not set out in the early 20's or 30's. Left political forces, few in number, disorganized and without support, failed in their attempt to oppose the state and for over 15 years in Albania was set Monarchy (1924-1939) who who declared war to communist ideas. European communist parties were formed two-three years after the founding of the International Communist. But echoes of Bolshevik power in Albania came dim because of backwardness and poor economic conditions of the country. Albania was an agrarian society, the mass was illiterate people, and the elite was anti-communist." 7

But World War II brought other developments, the overthrow of the monarchy and the country's occupation by Italy and then Germany. The Communist Party was founded by the Yugoslavs in 1941, but by the fall of 41 it was isolated. The coming to power of the communists was not via coup, but with regular elections, in 1945. Takeover of power was an

[1] Dervishi, Kastriot. "Shteti shqiptar 1912-2006" [The Albanian State 1912-2006], "55", Tirana 2007, p. 345

${ }^{[2]}$ Arendt, Hannah. "Origjinat e totalitarizmit" [The origins of totalitarianism], "Dija", Prishtina 2002, p. 422

[3] Velo, Maks. "Ese për diktaturën" ["Essay on the dictatorship"], "55", Tirana 2003, p. 11

[4] Arendt, Hannah, "Gjendja njerëzore" ["Human Condition"], "Dita", Tirana 2006, p. 134

[5] Idem, p. 104

[6] Arendt, Hannah. "Origjinat e totalitarizmit" [The origins of totalitarianism], "Dija", Prishtina 2002, p. 431

[7] Sadiku, Xhafer. "Genocidi mbi kulakët" [Genocide on kulaks], «ISKK», Tirana 2013, p. 30 
important moment for the future of the nation, but unfortunately the population did not understand that the state was complete dictatorship, the dictatorship of a single party led by the leader, out of a totalitarian regime in the full sense of the word." ${ }^{8}$ But, as it is known, this regime, gets its final form slowly progressively after eliminating his opponents.

For albanian communists, it was not easy to keep the power, more so on a largely uncontrolled and disorganized mass, if they did not rely on mechanisms and tools of totalitarian revolution. According to the example of Stalin's Bolshevik government, the government of Enver Hoxha originally launched with the liquidation of classes and forming of new classes in its favor. Until the 1957 reforms of Enver Hoxha, collectivization, which ended in 1956, nationalization, etc. had included almost the entire country. On the other hand it was created the state security, the secret police to execute their political opponents.

But only the mob and the elite can be attracted by the momentum of totalitarianism itself, measures should be introduced in propaganda, Arendt stresses." Propaganda is part of "psychological warfare" because it is the means, the most important instrument of totalitarianism, while terror is the very essence of its form of government. Just as the Nazis killed not only political opponents, wellknown figures, but small socialist functionaries, ordinary people, innocents, opposing beliefs, etc., they made massive terror to influence the masses to say there was no other way, even the Enver Hoxha's communism did the same thing. Hannah Arendt saw everything as a process closely associated with the leader. Enver Hoxha blindly worshiped Stalin and he was determined to make his country the only real communist country in the world. But since the post-war years this country lived as in enclosure, in a total disbelief to others. Inflexible and unyielding, he had transformed his country into a surrounded fortress, in a laboratory of a total collectivization and a society that wanted equality. Knowing and understanding the polotics consciously, he cut relations, as soon as he understood that dogma was nothing else but a game.

In the case when in his country there were people who opposed him and his principles, relentless violence was spilt over them, and they were even "suicided", as happened with the Prime Minister Mehmet Shehu (1981) or even with his old friends of the weapons. And every time, every episode that happened in this country Enver Hoxha was faking an entire nation, or showing a version of his own story. Like the other dictators he triumphed against his opponents, who were far more capable, this thanks to his great popularity.

Like Hitler or Stalin, Enver Hoxha had many supporters, but he expanded a lot the number of his supporters and limited the number of the members of the Communist Party. As we know, supporters are from all sides and not innocuous in a totalitarian movement, they serve as a shield, as a normality fog for all members and movement. On everyone's mind was entrenched the principle that the leader is irreplaceable, and he triumphed over everything. No one could criticize him. Enver would not allow himself criticism from his subordinates, and all were acting in his behalf. Enver Hoxha did any crime and did not stop at nothing. Established a strong cult of the individual so that Stalin himself would envy. "Communism in Albania had more characteristics of a mafia organization, rather than a genuine political system and society. The basic structure as in classic mafia was family clan. Family members, relatives, members of the tribe were placed in the most important positions. For opponents, those who thought differently, had only revenge and physical elimination. "10

To keep the power built on hundreds of innocent victims, he used the secret services, the State Security was entirely dependent on the will of the leaders, and was the latter that decided who would be the next enemy. Security task was not to reveal the crimes, but to be available to the government and leaders. Security did not care about the individual, because to it the individual is just an "enemy" to disappear in the long list. Today in the archives of the Ministry of Internal Affairs has over 10 folders of convicted individuals, thousands of other people who are kept under scrutiny, or folders for other people who might be potential to be destroyed as "enemies " of the power and of the leaders. Officially in Albania there were not concentration camps, in the classical sense as in Nazi Germany, but had dozen of labor camps, "education" that for cruelty, ill-treatment and conditions were worse than Hitler's camps. These labor camps were built in the entire country, from north to south, from east to west. They are filled with enemy element, the descendants of political prisoners who were detained or shot. They did not spare neither women nor children, elders or disabled. The enemy was everywhere.

In labor camps in the socialism of Enver Hoxha served as laboratories of their experiment, because there were proved inhumane tortures, terror, panic, etc., there disappeared innocent people who had done nothing but who suffered the condemnations and tortures only by "fault " of someone else. In camps human beings were humiliated, violated, raped, destroyed. People were simply human, rats model, animals, or worthless items.

${ }^{[8]}$ Arendt, Hannah, "Origjinat e totalitarizmit" [The origins of totalitarianism], "Dija", Prishtina 2002, p. 400

[9] Idem, p 414

[10] Velo, Maks. "Ese për diktaturën" [Essay on the dictatorship], "55", Tirana 2003, p. 75 
Hannah Arendt one of its essential characteristics of totalitarianism qualifies robbery of people's lives, not only in terms of view, physical, directly, taking the life of peole, but also human dignity strip, to take everything from a man, all his rights and to put it as a pet that goes towards the end itself, willingly, without any kind of resistance. Destroying people's individuality, simply makes it invisible, so that his existence does not matter anymore, is he or not.

"In all cases, for a SS or a Bolshevik, writes Arendt, death is as common as the murder of a man and to him this is the same as typing a fly". ${ }^{11}$ All this was nothing but a terrorist. And terror in Albania, as elsewhere, did not choose its victims, they could be peasants, workers, they could be highlandes, generals, students, women, children. Today there are many books publishing evidence and reports of survivors of these labor camps of bloody regime of Enver Hoxha, which prove barbarism, cruelty to man, and this had never happened before so massively and so cruelly.

For the above and many other facts, documents and evidence from the dictatorial regime of Enver Hoxha, it can be said without fear that Albania really experienced a totalitarian regime. The case of Albania has not been studied from foreigners, not only for the simple fact that it is a small geographically country and politically isolated, but also for the other fact that has always been irrelevant in politics world and that its isolation did not affect Europe or the world. In these two and a half decades of freedom, Albanians and Albania have proven to be a European nation that loves freedom and that totalitarian regime, 50-year-old was not the will of their choice.

\section{References}

Dervishi, Kastriot. "Shteti shqiptar 1912-2006" [The Albanian State 1912-2006], "55", Tirana 2007

Arendt, Hannah. "Origjinat e totalitarizmit" [The origins of totalitarianism], "Dija", Prishtina 2002

Velo, Maks. "Ese për diktaturën" [Essay on the dictatorship], "55", Tirana 2003

Arendt, Hannah, "Gjendja njerëzore" [Human Condition], "Dita", Tirana 2006

Sadiku, Xhafer. "Genocidi mbi kulakët" [Genocide on kulaks], «ISKK», Tirana 2013, p. 30

Arendt, Hannah. "Sulla violenza", "Guanda", Parma 1996

Berlin, Izajah. "Katër ese për lirinë" [Four essays on freedom], "Onufri", Elbasan 1996

Castellan, Georges. "Historia e Ballkanit" [History of the Balkans]. "Çabej", Tirana 2003

Lakër, Uollter. "Europa në kohën tonë"[ Europe in our time.] "Dituria", Tiranë 2003

Poliakov Leon, "Totalitarizmat e shekullit XX"["Totalitarianism of the twentieth century"], "Përpjekja" Tirana 2000

[11] Arendt, Hannah, "Origjinat e totalitarizmit" [The origins of totalitarianism], "Dija", Prishtina 2002, p. 588 